\title{
REPRODUCTIVE CHOICE: INTERNATIONAL ETHICAL STANDARDS AND PROSPECTS FOR LEGAL REGULATION IN CERTAIN EUROPEAN COUNTRIES
}

DOI: $10.36740 /$ WLek202009230

\author{
Kateryna V. Nykolyna \\ TARAS SHEVCHENKO NATIONAL UNIVERSITY OF KYIV, KYIV, UKRAINE
}

\begin{abstract}
The aim: The article is aimed at elucidating the prospects for the formation of universal ethical and legal standards in the work of medical workers in order to ensure the reproductive choice of a person according to the analysis of international documents, court practice of the ECHR, and the national legislation of individual European countries. Materials and methods: Research materials include scientific developments of both domestic and Western theorists and human rights defenders in the field of medical law in the aspect of reproductive choice. The recommendations of the Center for Reproductive Rights in the USA, the World Health Organization, the United Nations, and the ECHR practices were of great importance. This article used the methods of searching, analyzing, organizing, and summarizing information.

Conclusions: It is necessary to ensure the provision and guarantee of reproductive choice for everyone at the level of the Constitution. Given the public debate about the contradictions of individual manifestations of reproductive autonomy, it is proposed at the first stage of legal regulation to develop national principles and ethical standards for medical workers in this area.
\end{abstract}

KEY WORDS: reproductive choice, informed consent, post-mortal reproduction, reproductive rights

Wiad Lek. 2020;73(9 p. II):2056-2061

\section{INTRODUCTION}

One of the main achievements of the second half of the XXI century was the development of science, technology, and production. However, the twentieth century is not only marked by the highest achievements in science but also a fundamental rethinking of what the human body is, what its status is, and what the boundaries of everyone's physical freedom are. In fact, the world is moving into the realities of a new socio-legal paradigm. A person's desire at the right moment of one's life to consciously escape from suffering, to improve or change one's body with medical technologies, to recreate one's essence by cloning or to model one's own body in a nonmetric form of objective existence, etc gave rise to a new legal phenomenon - somatic human rights (from the Greek soma - body). These human rights to free use of the body arose not only in the last two centuries: specific issues concerning the human right to homosexual contacts, prostitution, and sterilization have long been interested for legal science, but due to their specificity, they were always outside the law, outside of society, and its moral and ethical standards.

This year marks two important dates in the history of reproductive health: 50 years since the start of activities of UNFPA and 25 years since the time of conduction of the momentous event - the International Conference on Population and Development (ICPD) in Cairo. The 2019 population health report reflects the current state of sexual and reproductive health and rights 50 years after the establishment of the United Nations Fund for Population Activities (UNFPA). "During this time, the collaborative efforts of civil society, governments, development agencies, and UNFPA have opened up new perspectives and opportunities for women and girls around the world. Nevertheless, we still have a long way to go before all women and girls will use the real opportunity and the means to allow them to manage their own body and make informed decisions about protecting their sexual and reproductive health," Natalia Kanem, Executive Director of UNFPA says in the preface of the report [1].

An important component of ensuring reproductive human rights is the guarantee of free reproductive choice (reproductive autonomy) of couples or individuals to freely and responsibly choose the time, number and interval between their children [2]. The development of medical and biotechnology today creates new challenges for the ethical and legal regulation of the right to manage one's reproductive health. This also includes post-mortal (post-mortem) reproduction, the use of assisted reproductive technology for persons of ripe years, for HIV-infected parents, and others. However, as noted in the medical literature, when trying to formulate universal international standards for applying the right of free reproductive choice, certain contradictions between demographic priorities and reproductive choice and contradictions between the universal concept of human rights and national customs/religion arise [2]. 


\section{THE AIM}

The article is aimed at elucidating the prospects for the formation of universal ethical and legal standards in the work of medical workers in ensuring the reproductive choice of a person according to the analysis of international documents, court practice of the ECHR, and the national legislation of individual European countries. The task is to develop scientific and practical proposals for legal regulation in certain countries of Europe in the specified sphere of public relations.

\section{MATERIALS AND METHODS}

As for the materials used, among them, there are relevant scientific developments of both domestic and Western theorists and human rights defenders in the field of medical law. The materials of the Center for Reproductive Rights in the USA, the World Health Organization, and the United Nations are important for the analysis. Since reproductive rights are part of human rights, the international human rights standards set forth in the conventions and the practice of the ECHR are the material basis of the study.

\section{REVIEW}

Reproductive healthcare providers must take into account not only the ethical considerations inherent in their work but also human rights standards regarding reproductive rights. The difficulty lies in the fact that the development of these standards is faced with certain problems.

The foundations of the concept of reproductive rights were laid in 1968 at the Tehran International Conference on Human Rights, when they recognized the right to freely, with a sense of responsibility, determine the number of children and the time of their birth [3]. In paragraph 7.2 of the Program of Action of the International Conference on Population and Development, which was held in Cairo on September 5-13, 1994, it was noted that reproductive health is not just evidence of the absence of diseases of the reproductive system or impaired function, but it is a state of complete physical, mental, and social well-being, which provides for the possibility of a satisfactory and safe intimate life, the ability to reproduce, the right of men and women to information and access to safe, effective methods of family planning and other contraceptive methods that they choose, which do not contradict the law, as well as the right to access to appropriate health care services, which allow a woman to safely endure pregnancy and childbirth and parents to create the best conditions for the birth of a child. However, not all states have accepted the inclusion of reproductive rights as part of internationally recognized human rights. At the Cairo Conference, several countries (usually for religious reasons) expressed official warnings regarding the concept of reproductive rights or its specific content [4].

The issue of reproductive rights was further developed in paragraph 95 of the Program of Action, which was approved by the Fourth World Conference on Women in Beijing on September 4-15, 1995. This act states that reproductive rights are based on a set of fundamental rights: all married couples and individuals freely can make a responsible decision regarding the number of children, the intervals between their birth, the time of their birth and possess the necessary information and means for this; rights to achieve the highest possible level of sexual and reproductive health, including the right to make decisions on issues related to reproductive behavior in the absence of discrimination, coercion, and violence; to receive information and access to safe, effective family planning methods and related health services [5].

Unfortunately, some conservative political and religious forces continue to stand against certain means of protection and promotion of reproductive rights. Access to contraceptives, although not always explicitly prohibited, is not adequately provided in some countries. Legal abortion in most European Union countries has been largely liberalized by legislative and judicial decisions, however, there are legal obstacles in some countries [6].

The World Health Organization defines reproductive rights as follows: Reproductive rights are based on the recognition of the fundamental right of all couples and individuals to freely and responsibly determine the number of their children and intervals of their births, as well as to have the information and means to do so, as well as the right to attainment of the highest sexual level and reproductive health. They also include the right of all people to make decisions on reproduction without discrimination, coercion, and violence [7].

From this definition it is logically possible to distinguish basic reproductive human rights: the right to freely choose the number of children and the time of their birth (including the right to refuse the birth of children); the right to information to achieve the highest level of reproductive health; the right to obtain means to achieve the highest level of reproductive health (including access to reproductive technologies); the right to the reproductive choice.

Reproductive choice (or reproductive autonomy) is an opportunity to make decisions independently about one's own reproduction, free from discrimination, coercion, or violence.

However, the biggest problem is that there is no detailed legal regulation of reproductive rights, both at the national and international level. To date, this area of public relations is governed by the documents adopted at the World Conferences and the Convention on Human Rights for Biomedicine. The European Convention for the Protection of Human Rights and Fundamental Freedoms is of particular importance. Despite the fact that none of its articles directly regulates reproductive rights, however, the ECHR has developed a fairly broad practice in protecting them using Articles 2, 8, 12 (right to life, right to respect for privacy and family life, non-discrimination).

Attempts to consolidate the definition of "reproductive rights" and to improve the legal regulation of relations in the sphere of their exercise have been also made in Ukraine. In February 2004, a draft law of Ukraine "On Reproductive 
Rights and Guarantees of their Exercise" was developed [8]. Strong objections to its adoption were raised by religious communities and organizations. In July 2005, a draft law on Reproductive Health [9] also sparked much debate. It should be noted that as of 2019, there is no single legislative act in Ukraine that would specifically, comprehensively and clearly enshrine the reproductive rights of an individual, determine their specificities, and guarantees of exercise.

\section{DISCUSSION}

The absence of legal regulation of the exercise of rights in the Institute of Reproductive Technologies is not clearly regulated in national legislation. The lack of thorough studies at the national level in this area is explained by the fact that the widespread use of artificial insemination methods and, consequently, reproductive technologies is not widely known to the public. In addition, in Ukrainian society, as in some other countries in Europe, the support of traditional family values and Christian morality prevail, as a result, interventions in the reproductive field are treated with caution and sometimes considerable criticism.

However, the right to reproductive autonomy is an integral part of the right to health and therefore cannot be denied as a natural human right. People are free and no one can be compelled to do or refrain from committing actions other than on their own free will. And the medical field is no exception. Any medical intervention, including in the reproductive field, should be carried out with the consent of the individual only.

Reproductive choice (autonomy) should be based on the informed consent concept, which is to inform the patient of all possible risks of diagnosis, treatment, or abstention from medical intervention, and to express the patient's consent. Informed consent can be understood as a requirement of respect for the right to self-determination as a means of ensuring personal freedom [10].

The problem of reproductive choice also arises in the context of post-mortem reproduction. At present, this issue is being actively discussed in medical science [11]. The particularly relevant question: Is it possible to consider the right of the wife/close relatives to use the deceased's reproductive material as part of the right to reproduction? In the context of the military conflict in Ukraine, when many soldiers die, the answer to the question becomes crucial for their wives. To date, only the US and Israel have a legislative provision about the mandatory collection of biological reproductive material from military personnel sent to the war zone.

Today, there are several options for posthumous reproduction: the use of cryopreserved sperm (or ovum) taken during a person's life or the transfer of previously frozen embryos, as well as a completely new direction - the posthumous removal of sperm of a deceased man. If everything is clear with the first two methods, then post-mortem sperm collection raises a huge number of both medical and ethical-legal issues. First of all, it is possible to do by the method of electro-ejaculation, which stimulates the ejacu- latory mechanism of the deceased man. It uses TESE (testicular sperm extraction), PESA (percutaneous epididymal sperm extraction, i.e. through the skin, sperm collection from the epididymis), and TESA (percutaneous aspiration of sperm from testicular tissue) technologies. In addition, the testicles of a man may be posthumously removed to obtain sperm. Regardless of the type of application of the technique, sperm collection should be carried out within 24-36 hours after the death of a man, immediately after which the sperm is cryopreserved for further use in the protocol of assisted reproduction technologies. And here the problem arises: how to establish whether the deceased agreed to such a collection of reproduction material: Can the reproductive choice be made by his wife/close relatives?

In some states (Germany, Denmark, France, Switzerland, Sweden) posthumous reproduction was prohibited, and in a number of countries (Belgium, Great Britain, Israel, the Netherlands, USA, etc.) it is carried out legally [12].

Taking into account foreign experience, one should agree with the proposal to establish at the level of national legislation (for states that do not prohibit post-mortal reproduction) the form for obtaining the donor's consent to use reproductive material after death, to define a clear circle of persons entitled to such a use, to establish the status and the inheritance rights of the child born as a result of such a reproduction [13]. In addition, it should be borne in mind that the period during which it is possible to perform posthumous removal of reproductive material is very limited in time. Involvement of the judiciary to decide on the presence or absence of prior consent (if it was not recorded in writing) will not always be appropriate, since the duration of the trial, as a rule, exceeds the necessary 24-36 hours for the collection of biological material. Obviously, in this case, it is necessary to develop detailed medical protocols, in which the mechanism for establishing the prior consent of the deceased should be clearly defined.

Separately, the issue of reproductive autonomy of the disabled should be raised. In the healthcare sphere, they face many discriminatory practices. Women and girls with disabilities are especially vulnerable to forced medical intervention in reproductive health [14]. In this context, the provisions of the Convention on the Rights of Persons with Disabilities should be implemented in national legislation as ethical and legal standards. It was ratified by Ukraine on December 16, 2009, and reaffirms the rights of women and girls with disabilities to reproductive autonomy, including autonomy related to reproductive health, along with persons without disabilities.

The importance of legislative consolidation of such a right is that it will protect patients with disabilities from the psychological pressure of medical workers aimed at refusing to give birth to children. This is precisely the problem that concerns the Ukrainian married couple with cerebral palsy, who became parents in 2017: "We really wanted a child. I knew that asking the doctors for permission didn't make sense - they were unlikely to allow doing that. Therefore, when I became pregnant, I did not go to the maternity welfare center immediately. I felt that the 
child was developing well. Then, of course, I often heard: "how do you carry pregnancy to term with your bunch of diseases"? I went on bed rest, but the attitude of the doctors was bad. I left the hospital on the third day and led an active lifestyle until the very birth. I understood that the health of the child is in my hands "[15]. Thus, the lack of proper legal regulation in this area leads to the growth of a large number of problems with the procedure for applying guarantees of reproductive choice.

However, to be fair, it is worth noting that on February 7,2019 , two alternative draft laws on reproductive rights "On assisted reproductive technologies" were registered in parliament. The authors proposed establishing at the legislative level the determination of the definitions of infertility, donation of oocytes (ovum), sperm, embryos, a reproductive cell donor, surrogate maternity (surrogacy), reproductive cells and tissues, etc. The importance of such a legal regulation lies not only in protecting the rights of patients, but also in securing guarantees for medical workers. Legislative regulation is the basis for the development and approval of national medical protocols for the use of reproductive technologies.

The analysis of the existing legal regulation indicates that the provision of the right to reproductive technology is connected exclusively with medical indications and is considered by the legislator only as a method of treatment of infertility. However, today, there are situations when assisted reproductive technologies can be applied in non-treatment cases. As a result of the increase in the number of natural disasters, cancer diseases, mortality in the war zone, relatives and spouses of the dead are increasingly turning to doctors to "create" a new life, posthumously using the genetic material of a person close to them. It is clear that when making such a decision, the interests of all parties should be taken into account: the deceased parent (s), the party initiating the protocol of artificial insemination (husband/wife, parents or close relatives of the deceased) and the future child.

However, when it comes to the question of the need to fully consolidate these rights, one should turn to the relation between law and bioethics. Thus, the Ukrainian scientist M. Medvedeva, who deals with the issues of somatic human rights, identifies three models of the interaction of ethics and law: sociological (under which the right is not able to solve complex ethical dilemmas and is not the main regulator of such a public relation), formalistic (the right plays the leading role in the regulation of all bioethical issues), and liberal (the law enshrines only some bioethical principles) [16].

We believe that the development of somatic human rights will depend on which model for the regulation of bioethical issues will be chosen by society and the state. It should be noted that not all scientists and practitioners support the legislative consolidation of somatic human rights. In general, the admissibility of a particular practice by law signals to people that this practice is clever (though in certain circumstances) despite the fact that previously this could be considered inadmissible [17].
Evidence of a violation of the right to reproductive autonomy is the ECHR's classic citation in Case "Tysiak v. Poland" under No. 5410/03 dated 24 September 2007. The applicant was refused to do a therapeutic abortion after being warned that her severe form of myopia could worsen if she carried pregnancy to term. Immediately after the birth of the baby, her retina started to bleed, which made her a disabled person.

The European Court of Human Rights found that the applicant had been denied the right to access effective mechanisms that could determine whether the conditions for legal abortion were in breach of Article 8 (right to respect for private and family life) of the European Convention on Human Rights [18].

The similar situation in Ireland illustrates the case considered by the ECHR on application A., B., and C. v. Ireland (application no. 25579/05) dated December 16, 2010. Three women living in Ireland who became pregnant unintentionally contested the fact that due to their inability to perform a legal abortion in Ireland, they had to travel to the United Kingdom. The applicants noted that this procedure was humiliating, shameful, and risky to their health. Performing or assisting anyone with abortion is a criminal offense in Ireland. However, there is a constitutional right to abortion if there is a real and significant risk to the mother's life. One of the applicants, who was in remission of a rare form of cancer and was unaware of her pregnancy, was being treated. The Court held that Ireland had failed to secure the applicants' constitutional right to legal abortion. Thus, Article 8 (right to respect for private and family life) of the Convention was violated. The court noted that the ambiguity about the determination of the woman's pregnancy posed a threat to her life and the threat of prosecution of medical professionals had a significant impact on the decision of the doctors [19].

Nowadays, one of the reasons for the abuse of reproductive rights is expressed in the modern medical literature - the existence of gender stereotypes. For example, in a new study, "The Impact of Gender Stereotypes on Human Rights in the Context of Reproductive Health", Chiara O'Connell and Christina Zampas justify the existence of a stereotype about women's vulnerability and inability to make decisions about their health. Instead, men and people in leadership positions, such as physicians who perform medical procedures, male members of the family, or society as a whole, are more empowered to make decisions for women.

This stereotype acts so that women are denied information to make reasoned decisions about their reproductive health and replace the decisions of others with their own [20]. We are talking about "paternalistic control" by doctors, who, using medical knowledge and abusing medical terms, actually make decisions instead of the patient. In the aspect of reproductive rights, such an effect may consist of not providing a woman with complete information about alternative options (for example, to continue or terminate a pregnancy) [21].

Given the possible negative consequences for both the physical and psychological health of a woman, we suggest 
reinforcing the obligation of healthcare professionals to provide written explanations to the patient of its reproductive rights in each case. Rebecca Cook also emphasizes this role of the physician, noting that it will facilitate the consolidation of individual choice and not distort it [22]. To address this problem, FIGO has developed and issued ethical standards "Harmful stereotyping of women in health care», recognizing the harmfulness of stereotypes about women in health care, and giving recommendations to obstetricians and gynecologists on identification and avoidance of the stereotypes of both patients and colleagues [23].

The legislative concept of the informed consent or the right to make informed choice for one's own future requires that health professionals would refrain from paternalistic control and instead provide women with the information, which is not coercion or personal preferences. The definition of the informed consent of the International Federation of Gynecologic and Obstetric Institutions states: "It is important to remember that informed consent is not a signature but a process of communication and interaction. [...] If doctors, due to their own religious or other beliefs, do not want to fulfill the criteria of the informed consent because they do not wish to provide information about certain alternatives, they have an ethical obligation, in respect to their patients' rights, to open their objections and to take appropriate directions, while respecting the rights of their patients, open their objections and make appropriate referrals so that patients can obtain the full information they need to make free and informed choices"[24]. We believe that these recommendations must be implemented in the national system of law when adopting legislation in the field of reproductive rights.

Social progress can not be stopped by artificial restraint, and since there is a demand for certain rights that a person cannot exercise without state authorization (often as a result of outright prohibition of such actions), they have to find their own legislative consolidation sooner or later. In today's world, people are given more opportunities, but as a result of increasing responsibility for their lives, they have to choose these opportunities independently and responsibly. It is the duty of the state to give the society the rights it requires and the real mechanism for their implementation; it is the duty of the society and the individual to realize the consequences of such changes and to put them or not to put them into life.

\section{CONCLUSIONS}

To summarize, we can draw some conclusions and generalizations:

1. States, depending on the level of legal regulation of reproductive rights, can be conditionally divided into: liberal, which provide broad reproductive rights and provide free reproductive choice (USA, Belgium); paternalistic, which, because of religious influence and national traditions, significantly limit their reproductive choices (Islamic countries, Ireland, Croatia); those, which do not have legal regulation of reproductive choice (Ukraine, Russia).
2. The lack of legal regulation of reproductive choices and reproductive rights significantly complicates their implementation and protection.

3. Given the considerable public and scientific discussions regarding a clear list of reproductive rights and their scope, due to the influence of religious organizations and the support of traditional family values, in some European countries (Ukraine, Poland, Croatia, Hungary, etc.), it is proposed in the first stage to consolidate guarantee of their provision by the state at the level of the Constitution.

4. In the next stage, it is proposed to develop a Concept for the development of national legislation in the field of reproductive rights, taking into account ethical and legal international standards and to consolidate the following principles: freedom of reproductive choice; equal access for men and women to reproductive technologies; non-discrimination in the field of reproductive rights; tolerance of health professionals in relation to all groups of patients; insurance of the confidentiality and privacy in the application of reproductive technologies; responsibility for violation of free reproductive choice. Of course, reproductive rights have arisen in connection with the public need and rapid development of medicine, biology, and chemistry. However, along with all the useful novelties that bring scientific and technological progress, significantly improve the standard of living, and create opportunities, which the society has not previously been able to use, the active development of such rights (including the state authorization of negative aspects of such rights) can lead to unheard-of consequences, after which the condition of the human society will no longer be able to return to its primary condition. In addition, this category of rights is quite specific and, at present, the theoretical paradigm of its functioning has not yet been fully formed. There are a number of questions before humanity that must be answered before these rights can coexist with previous generations of rights.

\section{REFERENCES}

1. "State of world population 2019. Unfinished business: the pursuit of rights and choices for all». Report of the United Nations Population Fund (UNFPA). 2019.

2. Freedman L., Isaacs S. Human Rights and Reproductive Choice. Studies in Family Planning. 1993; 24(1): 18-30. doi:10.2307/2939211

3. ZaklykTegheransjkoji konferenciji 00N vid 13 travnja 1968. doi://zakon4. rada.gov.ua/laws/show/995_900.

4. Doklad Mezhdunarodnoi konferentcii po narodonaseleniiu i razvitiiu (Kair, 5-13 sentiabria 1994 goda). Izdanie Organizatcii Obedinennykh Natcii/ 1995:189. (in Russian).

5. Chetvertaia Vsemirnaia konferentciia po polozheniiu zhenshchin (Pekin, 4-15 sentiabria 1995 g.) doi://www.un.org/womenwatch/daw/ beijing/pdf/BDPfA\%20R (in Russian).

6. Cook R.J., Dickens B. From Reproductive Choice to Reproductive Justice. International Journal of Gynecology and Obstetrics/ 2009;106: 106-109.

7. Gender and human rights. WHO. doi://www.who.int//reproductivehealth/gender/index.html

8. Pro reproduktyvni prava ta gharantiji jikh zdijsnennja: proekt Zakonu Ukrajiny vid 10.02.2004 r. \# 5105. (in Ukrainiane). 
9. Pro okhoronu reproduktyvnogho zdorov'ja: proekt Zakonu Ukrajiny vid 12.07.2005 r. \# 5369. (in Ukrainiane).

10. Pereira C.. Two visions of informed consent. Journal of Advanced Pharmaceutical Technology and Research. 2016; 4: 134-140.

11. Rothman C.M. A method for obtaining viable sperm in the postmortem state. 2001; 76: 841-3.

12. Sabatello M. Posthumously Conceived Children: An International and Human Rights Perspective. 27 J.L. Health. 2014; 29.

13. Pashkov V., Gutorova N., Noha P. Reproductive function: the protection of the rights of the people which are sent to the area of the fighting. Wiadomości lekarskie. 2018; 71(2/2): 403-407.

14. Ngwena C. Reproductive autonomy of women and girls under the Convention on the Rights of Persons with Disabilities. International Journal of Gynecology \& Obstetrics. 2017; 140.

15. «Pobedytely po zhyzny». Interv'ju dlja elektronnogho vydannja.: doi://2day.kh.ua/pobediteli-sudby-istoriya-neobychnoj-semi/ (in Polish).

16. Medvedjeva M. Normy etyky ta prava v reghuljuvanni biomedychnykh doslidzhenj: mizhnarodno-pravovyj aspekt. Suchasni problemy bioetyky. Akademperiodyka. 2009: 121-124. (in Russian).

17. Ghrevcova R. Medychne pravo Ukrajiny: tendenciji i perspektyvy rozvytku v umovakh ghlobalizacijnykh ta jevrointeghracijnykh procesiv. 2014. doi://Icslaw.knu.ua/index.php/arkhiv-nomeriv/1-6-2014/ item/159-medychne-pravo-ukrainy-tendentsii-i-perspektyvyrozvytkuvumovakhhlobalizatsiinykh-taievrointehratsiinykhprotsesiv-hrevtsovar-yu (in Ukrainian).

18. European Court of Human Rights. Case of Tysiąc v. Poland, 20 March 2007, app. no. 5410/03

19. European Court of Human Rights. ECHR 2011/7 Case of A, B and C v. Ireland, 16 December 2010, no. 25579/05

20. O'Connell C., Zampas C. The human rights impact of gender stereotyping in the context of reproductive health care. International Journal of Gynecology and Obstetrics. 2019: 116-121.

21. Murgic L., Héber P.C., Sovic S., Pavlekovic G. Paternalism and autonomy: views of patients and providers in a transitional (post-communist) country. BMC medical ethics. 2015; 16(1): 65. doi:10.1186/s12910015-0059-z
22. Cook R. J. Women's health and human rights: the promotion and protection of women's health through international human rights law. World Health Organization. 1994.

23. FIGO Committee for the Study of Ethical Aspects of Human Reproduction and Women's Health. Harmful stereotyping of women in healthcare (2011). In: Ethical Issues in obstetrics and gynecology. London: International Federation of Gynecology and Obstetrics; 2012:28-32.

24. Ethical Issues in Obstetrics and Gynecology, FIGO Committee for the Study of Ethical Aspects of Human Reproduction and Women's Health. 2015.

\section{ORCID and contributionship:}

Kateryna V. Nykolyna: 0000-0002-8603-1013 ${ }^{\text {A, B, C, D, E, F }}$

\section{Conflict of interest:}

The Author declare no conflict of interest.

\section{CORRESPONDING AUTHOR Kateryna V. Nykolyna \\ Taras Shevchenko National University of Kyiv \\ 60 Volodymyrska St., Kyiv 01601, Ukraine \\ tel: +380673179205 \\ e-mail: nykkatya@gmail.com}

Received: 14.10 .2019

Accepted: 23.06 .2020

\footnotetext{
A - Work concept and design, B - Data collection and analysis, C - Responsibility for statistical analysis,
} D - Writing the article, $\mathbf{E}$ - Critical review, $\mathbf{F}$ - Final approval of the article 